\title{
ANALISIS KUALITAS PEMBIAYAAN PERBANKAN SYARIAH TAHUN 2006-2010
}

\author{
Oleh: \\ Dewi Indriana \\ Alumni Jurusan Ekonomi Pembangunan Fakultas Ekonomi \& Bisnis UMM \\ Idah Zuhroh \\ Fakultas Ekonomi \& Bisnis Universitas Muhammadiyah Malang \\ E-mail/No.Hp:idahz@yahoo.com/-
}

\begin{abstract}
The research is quantitative descriptive research done in three banks titled: "Analysis of Financing Quality in Syariah Banks Period 2006-2010”. The research purpose is to find out how much given debt influence and Loan to Assets Ratio (LAR) to Non Performing Loan. In this research, researcher took hypothesis that there's a significant influence between given debt, Loan to Assets Ratio (LAR) to Non Performing Loan in Syariah Banks period 2006-2010. From the result, it is found determination coefficient $\left(R^{2}\right)$ for data regression 0,467. It means that independence variable altogether are able to explain $47 \%$ variance of dependent variables, which is Non Performing Loan. Then from t test, it is found that given-debt variable has significant influence to NPL, it is proven that $T_{\text {count }}>T_{\text {table, }}$ while LAR has unsignificant influence, it's proven that $T_{\text {count }}<T_{\text {table }}$ and after $f$ test, it is found that given-debt variable and LAR overall has significant influence to NPL. From data analysis done at once, it's shown that debt variable given has more significant result to NPL than LAR, which is $0,677 \%$.
\end{abstract}

keywords: given debt, LAR, Non Performing Loan

\begin{abstract}
Abstrak
Penelitian ini adalah jenis penelitian yang bersifat kuantitatif deskriptif yang dilakukan pada 3 bank yang berjudul "Analisis Kualitas Pembiayaan Perbankan Syariah Tahun 2006-2010”. Penelitian ini bertujuan untuk mengetahui seberapa besar pengaruh Kredit yang diberikan (pembiayaan) dan Loan to Assets Ratio (LAR) terhadap Non Performing Loan. Dalam penelitian ini, penulis mengambil hipotesa bahwa Di duga terdapat pengaruh yang signifikan antara Kredit yang diberikan, Loan to Assets Ratio (LAR) terhadap Non Performing Loan pada Perbankan Syariah Tahun 2006-2010. Dari hasil diperoleh nilai koefisien determinasi $\left(R^{2}\right)$ untuk regresi data sebesar 0,467. Hal ini berarti variabel bebas secara bersama-sama dapat menjelaskan $47 \%$ variasi variabel terikat yakni Non Performing Loan. Kemudian dari uji $t$ dapat diketahui bahwa variabel Kredit yang diberikan secara individual mempunyai pengaruh yang signifikan terhadap NPL, hal ini dibuktikan bahwa $T_{\text {hitung }}>T_{\text {tabel, }}$ sedangkan LAR mempunyai pengaruh tidak signifikan, hal ini dibuktikan bahwa $T_{\text {hitung }}<T_{\text {tabel }}$ dan setelah dilakukan uji f dapat diketahui bahwa variabel Kredit yang diberikan dan juga LAR secara keseluruhan mempunyai pengaruh signifikan terhadap NPL. Dari analisa data yang telah dilakukan secara serentak menunjukkan bahwa variabel Kredit yang
\end{abstract}


diberikan memiliki hasil yang lebih signifikan terhadap NPL daripada LAR, yakni sebesar $0,677 \%$.

Kata Kunci: Kredit yang diberikan, LAR, Non Performing Loan

\section{PENDAHULUAN}

Dunia Perbankan akan selalu menjadi sorotan publik, apalagi pada negara berkembang seperti Indonesia, yang dimana perbankan menjadi sektor paling berpengaruh dan diperhatikan sebagai acuan perekonomian dan stabilitas keuangan negara.

Dalam Undang-Undang (UU) Nomor 10 Tahun 1998 tentang Perbankan dan UU No 23/1999 tentang Bank Indonesia (BI). Mengatur tentang perkembangan pengembangan perbankan syariah di Indonesia. Indonesia memiliki penduduk yang mayoritas beragama Muslim. Apalagi, pengembangan perbankan syariah pada dasarnya, untuk memenuhi kebutuhan masyarakat yang selama ini tidak terlayani jasa perbankan konvensional karena masalah keyakinan, terutama yang berkaitan bunga bank. Di samping itu, pengembangan perbankan syariah merupakan bagian dari program restrukturisasi perbankan dalam kerangka peningkatan ketahanan sistem perbankan dan meningkatkan keragaman jasa perbankan.

Perbankan syariah sebagai "Lebih Dari Sekedar Bank" (beyond banking), yaitu perbankan yang menyediakan produk dan jasa keuangan yang beragam diantaranya pembiayaan dan pendanaan. Menurut Arifin (2000), konsep Islam adalah menjaga keseimbangan antara sektor riil dengan sektor moneter, sehingga pertumbuhan pembiayaan tidak akan lepas dari pertumbuhan sektor riil yang dibiayainya.

Tabel 1. Perkembangan Aset dan Pembiayaan Bank Syariah

\begin{tabular}{cccccc}
\hline \multirow{2}{*}{ Tahun } & \multicolumn{2}{c}{ Aset } & \multicolumn{2}{c}{ Pembiayaan } & \multirow{2}{*}{ FDR } \\
\cline { 2 - 5 } & Nominal* & Pertumbuhan & Nominal* & Pertumbuhan & \\
\hline 2005 & 20.880 & $36,25 \%$ & 15.232 & $32,58 \%$ & $97,91 \%$ \\
\hline 2006 & 26.722 & $27,98 \%$ & 20.445 & $34,22 \%$ & $98,90 \%$ \\
\hline 2007 & 33.016 & $23,55 \%$ & 27.944 & $36,68 \%$ & $99,76 \%$ \\
\hline 2008 & 49.555 & $50,09 \%$ & 38.199 & $36,70 \%$ & $103,7 \%$ \\
\hline 2009 & 66.090 & $33,37 \%$ & 46.886 & $22,74 \%$ & $89,70 \%$ \\
\hline 2010 (Sept) & 83.454 & $43,80 \%$ & 60.970 & $36,94 \%$ & $95,40 \%$ \\
\hline
\end{tabular}

Sumber: Diolah Statistik Perbankan Syariah BI 
Namun demikian, pertumbuhan pembiayaan yang tinggi dan terjaganya fungsi intermediasi yang baik selama tahun 2005 hingga 2010 triwulan ke 3 ternyata juga diikuti dengan memburuknya kualitas pembiayaan yang dilihat dari naiknya rasio kredit bermasalah (Non Performing Loan), atau dalam terminologi bank syariah disebut Non Performing Financing (NPF). Hal ini dapat dilihat dari tabel 1.2 berikut:

Tabel 2. Non Performing Financing (NPF) Bank Syariah

\begin{tabular}{cccc}
\hline \multirow{2}{*}{ Periode } & \multirow{2}{*}{ Total Pembiayaan } & \multicolumn{2}{c}{ NPL (financing) } \\
\cline { 3 - 4 } & & Nominal & $\%$ \\
\hline $2005-$ IV & 15.332 & 429 & 2.82 \\
\hline $2006-$ IV & 20.445 & 971 & 4.75 \\
\hline $2007-$ IV & 27.944 & 1.131 & 4.05 \\
\hline $2008-$ IV & 38.199 & 1.509 & 3.95 \\
\hline $2009-$ IV & 46.886 & 1.882 & 4.01 \\
\hline $2010-$ III & 60970 & 2.406 & 3.95 \\
\hline
\end{tabular}

Sumber: Statistik bank syariah BI

Inti utamanya adalah dengan

Bank Syariah akan menghindarkan diri dari bunga yang pada sebagian masyarakat muslim dianggap riba minimal meragukan (Jika meragukan lebih baik ditinggalkan). Selain itu Bank Syariah menerapkan prinsip yang lebih adil dan bersifat kemitraan dengan nasabah. Sebagai contoh adalah prinsip bagi hasil. Masyarakat yang memperoleh fasilitas pembiayaan dengan prinsip bagi hasil, dalam kondisi bisnisnya yang berkembang, yang bersangkutan akan memberikan kontribusi yang besar kepada masyarakat lain pemilik dana, namun jika kondisi bisnisnya mengalami penurunan karena kondisi yang tidak bisa dielakkan, tentunya kontribusinya akan berkurang.

Donny Prasetyo (2010) yang meneliti Pengaruh Modal Bank, Total Aktiva, dan Kredit yang diberikan terhadap Risiko Bank (Studi Empiris pada Bank yang terdaftar di Bursa Efek Indonesia Tahun 2003 - 2007). Berdasarkan penelitian tersebut peneliti menyimpulkan bahwa dalam uji hipotesis secara parsial hanya variabel aktiva dan kredit yang diberikan saja yang memiliki pengaruh terhadap NPL.

Anonim, jurnal penelitian terdahulu yang berjudul, Analisis Kinerja NPL Perbankan di Indonesia serta faktor-faktor yang mempengaruhinya, bahwa hubungan antara Non Performing Financing 
terhadap LDR, LAR, BI Rate, Inflasi dan Kredit adalah positif yang berarti apabila NPL Naik maka LDR, LAR, BI Rate, Inflasi dan Kredit yang diberikan pun ikut naik.

$$
\text { Relevansi penelitian ini }
$$
dibandingkan dengan penelitian sebelumnya adalah mencoba mengevaluasi kembali tentang faktor yang mempengrauhi kinerja NPL, dengan melakukan perubahan pada objek penelitian, tahun penelitian, dan variabel. Objek penelitian yaitu pada Bank Syariah Mandiri, Bank Muamalat, Bank Mega Syariah. Variabel yang digunakan dalam skripsi ini adalah; Kredit yang diberikan, LAR.

Pada Pasal 1 (butir 2) Undangundang Nomor 10 Tahun 1998 tentang Perubahan Atas Undang-undang Nomor 7 Tahun 1992 Tentang Perbankan, dikatakan bahwa Bank adalah badan usaha yang menghimpun dana dari masyarakat dalam bentuk simpanan dan menyalurkannya kepada masyarakat dalam bentuk kredit dan atau bentukbentuk lainnya dalam rangka meningkatkan taraf hidup rakyat banyak.

Dengan dikeluarkannya UU Nomor 7 Tahun 1992 tentang Perbankan dan UU Nomor 10 Tahun
1998 tentang Perubahan atas UU Nomor 7 Tahun 1992 tersebut, dunia perbankan Indonesia mengalami perubahan yang cukup mendasar. Ada beberapa cara dalam pengklasifikasian bank-bank di Indonesia, yaitu dilihat dari segi fungsi atau status operasi; kepemilikan; dan penyediaan jasa. Klasifikasi bank berdasarkan fungsi atau status operasi.

Menurut M. Syafi'i Antonio menjelaskan bahwa pembiayaan merupakan salah satu tugas pokok bank yaitu pemberian fasilitas dana untuk memenuhi kebutuhan pihak-pihak yang merupakan deficit unit.

Sedangkan menurut UU No. 10 tahun 1998 tentang Perbankan menyatakan "Pembiayaan berdasarkan prinsip syariah adalah penyediaan uang atau tagihan yang dipersamakan dengan itu berdasarkan persetujuan atau kesepakatan antara bank dengan pihak lain yang mewajibkan pihak yang dibiayai untuk mengembalikan uang atau tagihan tersebut setelah jangka waktu tertentu dengan imbalan atau bagi hasil."

Kredit bermasalah

(Non Performing Loan) merupakan kegagalan pihak debitur memenuhi kewajibanya untuk membayar angsuran 
(cicilan) pokok kredit beserta bunganya yang telah disepakati kedua belah pihak dalam perjanjian kredit. Menurut Joyosumarto (1994) kredit bermasalah adalah kredit dengan kolektibilitas macet ditambah dengan kredit-kredit yang memliki kolektibiltas diragukan yang berpotensi menjadi macet. Sedangkan menurut Asrof (1994) mengatakan bahwa kredit bermasalah adalah salah satu dari resiko pembayaran, khususnyaapabila sumber pembayaran yang diharapkan tidak cukup tersedia untuk membayar hutang.

Kredit bermasalah (Non Performing Loan) merupakan kegagalan pihak debitur memenuhi kewajibanya untuk membayar angsuran (cicilan) pokok kredit beserta bunganya yang telah disepakati kedua belah pihak dalam perjanjian kredit. Menurut Joyosumarto (1994) kredit bermasalah adalah kredit dengan kolektibilitas macet ditambah dengan kredit-kredit yang memliki kolektibiltas diragukan yang berpotensi menjadi macet. Sedangkan menurut Asrof (1994) mengatakan bahwa kredit bermasalah adalah salah satu dari resiko pembayaran, khususnya apabila sumber pembayaran yang diharapkan tidak cukup tersedia untuk membayar hutang.
Rasio ini mengukur kemampuan Bank dalam melunasi kewajiban kepada para deposanya dengan melikuidasi surat-surat berharga yang dimilikinya. Semakin tinggi rasio ini maka tingkat likuiditasnya rendah karena jumlah asset yang diperlukan untuk membiayai kreditnya makin besar.( Eka Setiajatnika, 2012).

\section{METODE PENELITIAN}

Penelitian ini yang digunakan adalah penelitian analisis kuantitatif deskriptif, yaitu dengan mengumpulkan data-data mengenai laporan keuangan. Peneliti melakukan pengamatan terhadap objek penelitian yang dipilih, kemudian dianalisis dan disimpulkan.

$$
\text { Penelitian ini menggunakan }
$$
sumber data sekunder yaitu data penelitian yang dipublikasikan atau telah diterbitkan oleh Bank Syariah Mandiri, Bank Muamalat, dan Bank Mega Syariah yang di terbitkan kepada masyarakat dalam bentuk dokumentasi. Yakni data mengenai Non Performing Loan (NPL), jumlah Kredit yang diberikan (pembiayaan), LAR dari website Bank Indonesia tahun 20062010.

Populasi penelitian ini adalah perusahaan perbankan syariah di 
Indonesia. Teknik pengambilan sampel yang digunakan adalah purposive sampling yaitu teknik pengambilan sampel berdasarkan pertimbanganpertimbangan tertentu. Pertimbangan tersebut adalah perusahaan perbankan syariah yang ada di Indonesia dan menerbitkan laporan keuangan secara berturut-turut mulai tahun 2006-2010, serta memiliki catatan pertumbuhan pembiayaan yang semakin meningkat.

Tabel. 2 Status Perbankan

\begin{tabular}{cl}
\hline No. & \multicolumn{1}{c}{ Status Perbankan } \\
\hline Bank Swasta Nasional Devisa \\
\hline 1 & Bank BNI Syariah \\
\hline 2 & Bank Muamalat \\
\hline 3 & Bank Syariah Mandiri \\
\hline Bank Swasta Nasional Nondevisa \\
\hline 1 & Bank central Asia (BCA) \\
& Syariah \\
\hline 2 & Bank BJB Syariah \\
\hline 3 & Bank Rakyat Indonesia \\
& Syariah \\
\hline 4 & Bank Mega Syariah \\
\hline 5 & Panin Bank Syariah \\
\hline 6 & Bank Syariah Bukopin \\
\hline 7 & Bank Victoria Syariah \\
\hline \multicolumn{2}{c}{ Bank Campuran } \\
\hline 1 & Bank Maybank Syariah \\
& Indonesia \\
\hline Sumber: Wikipedia
\end{tabular}

Variabel bebas merupakan variabel yang berpengaruh terhadap variabel lain. Variabel bebas dalam penelitian ini adalah kredit yang diberikan (pembiayaan), LAR, dan juga BI rate. Kredit yang diberikan (pembiayaan) Pembiayaan merupakan salah satu tugas pokok bank yaitu pemberian fasilitas dana untuk memenuhi kebutuhan pihak-pihak yang merupakan deficit unit.

$$
\text { Loan to Assets Ratio (LAR) }
$$

Rasio ini mengukur kemampuan Bank dalam melunasi kewajiban kepada para deposanya dengan melikuidasi suratsurat berharga yang dimilikinya

LAR $=\frac{\text { Total Kredit yang diberikan (Pembiayaan) }}{\text { Total Aset }}$

Dimana:

Total Kredit yang diberikan $=$ Total kredit yang diberikan, Total Aset $=$ Total Aset atau Total Aktiva Variabel terikat (Dependent Variabel). Variabel terikat merupakan variabel yang dipengaruhi variabel lain, yang merupakan variabel terikat adalah Non Performing Loan (financing).

Non Performing Loan (financing) Merupakan kegagalan pihak debitur memenuhi kewajibanya untuk membayar angsuran (cicilan) pokok kredit beserta bunganya yang telah disepakati kedua belah pihak dalam perjanjian kredit.

$\mathrm{NPL}=\frac{\text { Kredit }(\mathrm{KL}, \mathrm{D}, \mathrm{M})}{\text { Total Kredit }}$

NPL < 2\%: Dari segi kualitas aset sangat baik dengan risiko sangat minimal $2 \% \leq \mathrm{NPL}<5 \%$ : Dari segi kualitas aset baik 5\% $\leq$ NPL $<5 \%$ : Dari segi kualitas aset cukup baik $8 \% \leq \mathrm{NPL}$ 
$<12 \%$ :Dari segi kualitas aset kurang baik NPL $\geq 12 \%$ : $\quad$ Dari segi kualitas aset tidak baik dan diperkirakan kelangsungan usaha bank sulit diselamatkan.(Surat Edaran Bank Indonesia).

Uji Normalitas bertujuan untuk menguji apakah data tersebut berdistribusi normal atau tidak. Model regresi yang baik adalah data yang memiliki distribusi normal atau mendekati normal (Ghozali, 2001:74). Uji normalitas data dilakukan dengan menggunakan one sample kolmogrov smirnov test,dengan syarat jika asymp.Sig (2-tailed) $>0,05$, maka data tersebut berdistribusi normal. Sebaliknya jika asymp.Sig tailed) $<0.05$ maka data berdistribusi tidak normal.

Uji Asumsi Klasik.Uji Multikolinieritas bertujuan untuk menguji apakah model regresi ditemukan adanya korelasi antar variable bebas (independent). Model regresi yang baik seharusnya tidak terjadi korelasi diantara variable bebas (Ghozali,2001:57). Metode untuk mendeteksi adanya multikolinieritas dapat dilakukan dengan melihat angka variance inflation factor (VIF),yaitu dengan melihat berapa nilai tolerance
(1- $\mathrm{R}^{2}$ auxilary) dan berapa nilai VIFnya. Jka Tolerance $<0,1$ atau jka VIF>10,maka terjadi multikolinieritas (Multikolinieritas berbahaya).

Uji Autokorelasi bertujuan untuk menguji apakah dalam suatu model regresi linier ada korelasi antara kesalahan pengganggu pada periode $\mathrm{t}$ dengan kesalahan pada priode $\mathrm{t}-1$ (sebelumnya). Jika terjadi korelasi,maka dinamakan ada problem autokorelasi. Untk mendeteksi adanya autokorelasi didalam penelitian ini dilakukan dengan uji statistik Durbin-Watson dengan pengambilan keputusan ada tidaknya autokorelasi sebagai berikut (Gujarati, 2006) :

Bila nilai DW terletak antara batas atas atau upper bound (du) dan (4du), maka koefisien autokorelasi sama dengan nol, berarti tidak ada autokorelasi. Bila nilai DW lebih rendah daripada batas bawah atau lower bound (dl), maka koefisien autokorelasi lebih besar daripada nol, berarti ada autokorelasi positif. Bila nilai DW lebih besar daripada (4-dl), maka koefisien autokorelasi lebih kecil daripada nol, berarti ada autokorelasi negatif. Bila nilai DW terletak di antara batas atas (du) dan batas bawah (dl) ada DW 
terletak antara (4-du) dan (4-dl), maka hasilnya tidak dapat disimpulkan.

Uji Heteroskedastisitas bertujuan untuk menguji apakah dalam model regresi terjadi ketidaksamaan variance dari residual satu pengamatan ke pengamatan yang lain. Jika variance dai residual satu pengamatan ke pengamatan yang lain tetap, maka disebut Homoskedastisitas dan jika berbeda disebut Heteroskedastisitas (Ghozali, 2001:69). Metode yang digunakan untuk mendeteksi ada tidaknya Heteroskedastisitas adalah dengan menggunakan metode Scatterplots, yaitu dengan melihat penyebaran data yang diteliti. Jika ada pola tertentu,seperti titik-titik yang ada membentuk suatu pola tertentu,yang teratur (bergelombang, melebar kemudian menyempit) maka telah terjadi Heteroskedastisitas. Jika tidak ada pola yang jelas,serta titik-titik menyebar diatas dan dibawah angka 0 pada sumbu Y maka tidak terjadi Heteroskedastisitas.

Model Regresi linier berganda Alat analisis yang digunakan adalah Least Square Method dengan dasar persamaan sebagai berikut: $\mathrm{Y}=\mathrm{a}+\mathrm{b}_{1} \mathrm{X}_{1}+\mathrm{b}_{2} \mathrm{X}_{2}+$ $\mathrm{b}_{3} \mathrm{X}_{3}+\mathrm{e}$ Diamana: $\mathrm{Y}=$ variabel NPLa

$$
=\text { konstanta } \mathrm{b}_{1}=\text { slope } \mathrm{X}_{1}=
$$

variabel kredit yang diberikan (pembiayaan), $\mathrm{X}_{2}=$ variabel LAR, $\mathrm{X}_{3}=$ variabel $\mathrm{BI}$ rate $\mathrm{e}=$ residualUntuk mengukur signifikan positif maupun negative koefisien regresi secara parsial atau satu persatu dari variable bebas terhadap variable terikat. Rumusnya adalah :

$\mathrm{t}_{\text {hitung }}=\frac{b i}{S_{\text {bi }}}$

Keterangan

$\mathrm{T}=$ Koefisien $\mathrm{t}_{\text {hitung }}$

bi $=$ Koefisien regresi

Sbi $=$ Standar deviasi variable bebas Statement Hipotesa

Ho : $\beta_{1}, \beta_{2}, \beta_{3}=0$, tidak ada pengaruh yang signifikan antara variable bebas (x) terhadap variable terikat (Non Performing Financing) secara parsial.

Ha : $\beta_{1}, \beta_{2}, \beta_{3} \neq 0$, ada pengaruh yang signifikan antara variable bebas $(\mathrm{x})$ terhadap variable terikat (Non Performing Financing) secara parsial.

Kriteria Pengujian Jika $\mathrm{t}$ hitung $>\mathrm{t}$ table, maka Ho ditolak, dan Jika $\mathrm{t}$ hitung $<\mathrm{t}$ table, maka Ho diterima.

\section{PEMBAHASAN}

Multikolinieritas adalah adanya korelasi yang linier antara variabel- 
variabel bebas dalam model regresi.

Kolinieritas terjadi jika diantara variabel bebas terjadi korelasi satu dengan lainnya atau berkorelasi tetapi tidak lebih tinggi dari $\mathrm{R}^{2}$, maka dikatakan tidak terjadi multikolinieritas.

Tabel 3. Rekapitulasi Uji Multikolinieritas

\begin{tabular}{|c|c|c|c|c|c|}
\hline \multirow{2}{*}{ Model } & \multicolumn{3}{|c|}{ Correlations } & \multicolumn{2}{|c|}{ Collinearity Statistic } \\
\hline & Zero-order & Partial & Part & Tolerance & VIF \\
\hline Kredit & .464 & .658 & .647 & .718 & 1.392 \\
\hline LAR & .170 & -.323 & -.253 & .50 & 2.321 \\
\hline
\end{tabular}

Sumber Data : Diolah (SPSS)

Uji ini digunakan untuk melihat apakah dalam model regresi terjadi ketidaksamaan variance dari residual satu ke pengamatan yang lain.

Dengan melihat grafik plot antara nilai prediksi variabel terikat (ZPRED) yang menyebar (mengumpul), yaitu titik-titik mengumpul di angka nol pada sumbu Y, maka dapat disimpulkan tidak terjadi Heterokedastisitas. Hasil selengkapnya dapat dilihat pada Grafik berikut: dengan Residualnya diperoleh pola

Gambar 1. Scatter Plot

$$
\text { Scatterplot }
$$

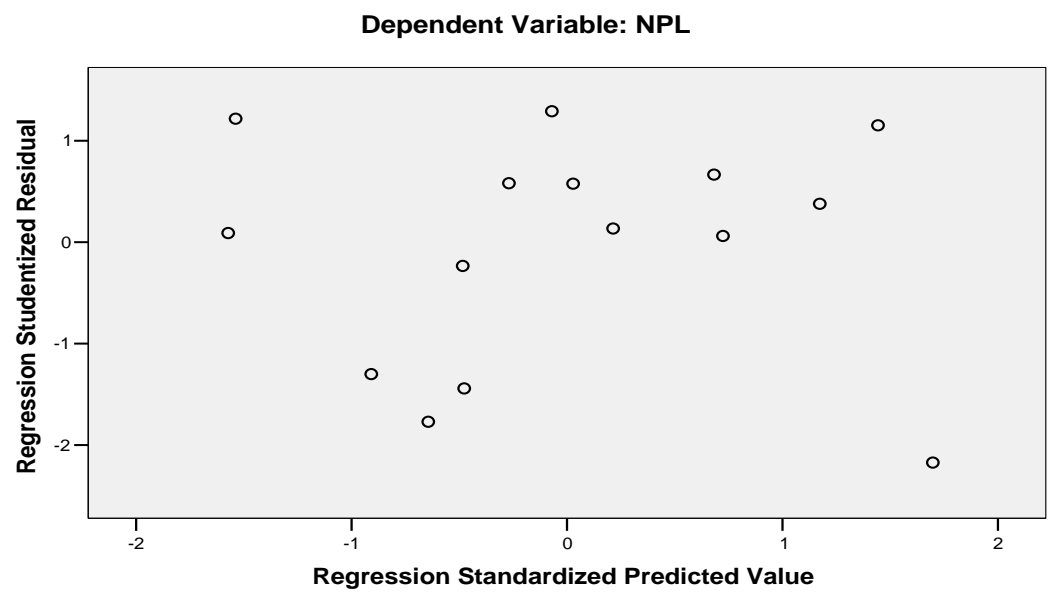

Autokorelasi digunakan untuk kesalahan pengganggu pada periode $\mathrm{t}$ menguji apakah dalam suatu model dengan kesalahan pengganggu pada regresi linier ada korelasi antara peridoe $\mathrm{t}-1$. Dari hasil perhitungan 
diperoleh nilai $\mathrm{DW}=0.783$. Karena nilai DW tersebut berada antara dibawah dl, maka diperoleh kesimpulan terjadi korelasi positif. Tabel 4. Rekapitulasi hasil uji Autokorelasi
Hasil Uji Durbin-Watson dapat divisualisasikan pada hubungan pola autokorelasi seperti gambar 2 .

Tabel 4. Rekapitulasi Hasil Uji Autokorelasi

\begin{tabular}{|l|r|r|}
\hline Model & $\begin{array}{c}\text { Std. Error of } \\
\text { the Estimate }\end{array}$ & $\begin{array}{c}\text { Durbin- } \\
\text { Watson }\end{array}$ \\
\hline 1 & 1.51827 & .783 \\
\hline
\end{tabular}

Sumber Data : Diolah (SPSS)

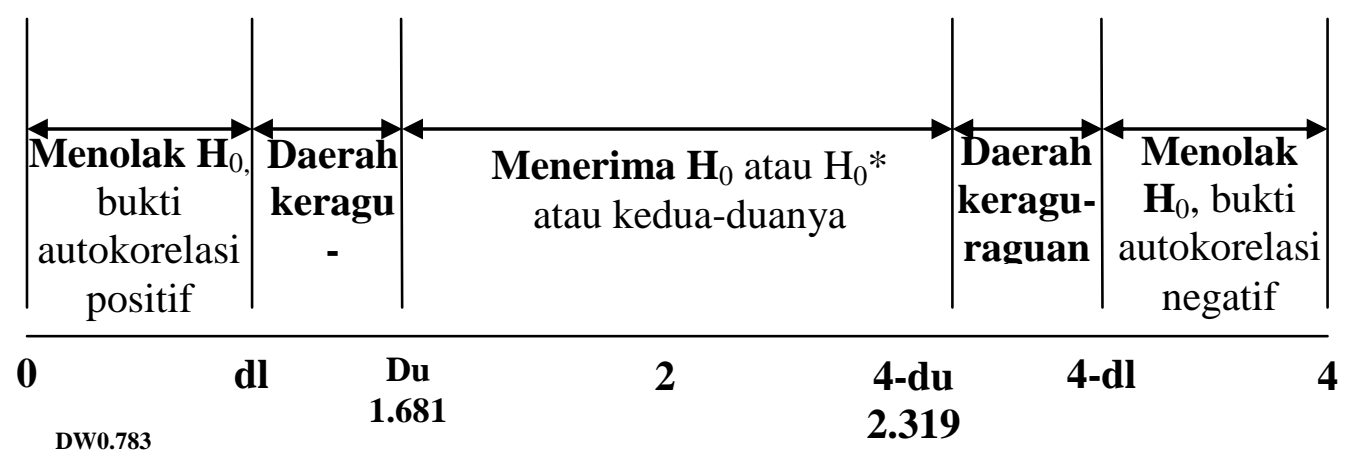

Gambar 2. Hasil Uji Durbin-Watson

Tabel 5. Rekapitulasi hasil uji regresi berganda antara Variabel Pembiayaan Yang Diberikan $\left(\mathrm{X}_{1}\right)$, Variabel LAR $\left(\mathrm{X}_{2}\right)$ dan Variabel BI Rate $\left(\mathrm{X}_{3}\right)$ terhadap Nilai NPL(Y)

\begin{tabular}{llccc}
\hline \multicolumn{1}{c}{ Variabel } & Koefisien Regresi & $\mathbf{t}_{\text {hit }}$ & Sign t & Keputusan \\
\hline Log Kredit & 0.677 & 3.200 & 0.008 & Signifikan \\
\hline Log LAR & \multicolumn{1}{c}{0.055} & 0.261 & 0.798 & Tidak Signifikan \\
\hline Constanta & $=-14.470$ & & & \\
R Square & $=0.467$ & & & \\
F-hitung & $=5.266$ & & & \\
Sig. F & $=0.023$ & & & \\
t-tabel & $=1.984$ & & & \\
$\alpha$ & $=0.5 \%$ & & &
\end{tabular}

Dengan berdasarkan hasil nol, maka nilai NPL sama dengan perhitungan regresi pada tabel diatas 14.470 .

didapatkan suatu persamaan garis regresi sebagai berikut:

$\mathrm{Y}=\mathrm{a}+\mathrm{b} 1 \log \mathrm{X} 1+\mathrm{b} 2 \log \mathrm{X} 2$

$\mathrm{Y}=-14.470+0.677 \mathrm{X} 1+0.055 \mathrm{X} 2 \mathrm{a}$

$($ intercept $)=-14.470$ berarti jika

variabel Kredit dan LAR sama dengan
Nilai koefisien regresi sebesar 0.677 yang berarti menunjukkan pengaruh variabel Pembiayaan atau kredit Yang Diberikan terhadap variabel terhadap NPL Yaitu bahwa dengan adanya perubahan pembiayaan yang diberikan sebesar satu \%, maka NPL 
akan meningkat sebesar 0.677.Nilai koefisien regresi sebesar 0.055 yang berarti menunjukkan pengaruh variabel LAR terhadap variabel terhadap NPL Yaitu bahwa dengan adanya peningkatan LAR sebesar satu \%, maka NPL akan menurun sebesar 0.055 .

\section{Koefisien Determinasi $\mathrm{R}^{2}$} sebesar 0.467 Dari besaran $\mathrm{R}^{2}$ tersebut dapat disimpulkan bahwa variabel Pembiayaan yang Diberikan, LAR dan BI rate menjelaskan keragaman dari dependent NPL yaitu sebesar $47 \%$. Sedangkan sisanya sebesar $53 \%$ dijelaskan oleh variabel lain yang tidak dimasukkan ke dalam model persamaan.

Guna melihat apakah variabel independen secara bersama-sama mempengaruhi variabel dependent secara nyata atau tidak, dengan menggunakan Uji $F$ yaitu dengan cara

Tabel 6. Rekapitulasi Hasil Uji Parsial

\begin{tabular}{lccc}
\hline \multicolumn{1}{c}{ Variabel } & T hitung & T tabel & Tingkat Signifikansi \\
\hline PembiayaanYang Diberikan, & 3.200 & 2.179 & 0.008 \\
LAR & 0.261 & 2.179 & 0.798 \\
\hline
\end{tabular}

\section{Variabel Pembiayaan Untuk} mengetahui sejauh mana kebenaran koefisien Regresi untuk variabel Pembiayaan digunakan uji t, dengan ketentuan sebagai berikut:

Ho $: \beta 1=0$ : artinya tidak ada pengaruh dari variabel membandingkan nilai $F_{\text {hitung }}$ dengan $\mathrm{F}_{\text {tabel. }}$.

Dengan pengujian uji $\mathrm{F}$ diperoleh nilai $F_{\text {hitung sebesar 5.266, }}$ sedangkan $\mathrm{F}_{\text {tabel }}$ pada taraf nyata $5 \%$ menunjukkan nilai sebesar 3.89 karena $\mathrm{F}_{\text {hitung }}>\mathrm{F}_{\text {tabel }}$ maka hipotesis nol (Ho) di tolak dan Hipotesa alternatif (Hi) diterima. Hal ini menunjukkan bahwa keduaa variabel independent secara bersama-sama mempengaruhi NPL. Dengan demikian hipotesa yang menyatakan Pembiayaan yang Diberikan, LAR secara simultan berpengaruh positif terhadap NPL dapat diterima. Untuk mengetahui ada tidaknya pengaruh masing-masing variabel bebas terhadap variabel terikat dilakukan pengujian secara parsial digunakan uji t. Adapun hasil uji $t$ adalah dapat dilihat pada tabel 6 . 
$t_{\text {tabel }}$ sebesar 2.179. Sedangkan dengan pengujian statistik diperoleh $t_{\text {hitung }}$ sebesar 3.200, karena nilai $t_{\text {hitung }}>t_{\text {tabel }}$, maka Ho ditolak dan $\mathrm{Hi}$ diterima.
Dengan demikian dapat diambil kesimpulan bahwa variabel pembiayaan adalah signifikan pada taraf nyata $\alpha=5$ $\%$ dengan tingkat kepercayaan $95 \%$.

Gambar 3.

Daerah Penerimaan dan Penolakan $\mathrm{H}_{0}$ dengan menggunakan uji $t$ terhadap variabel Pembiayaan

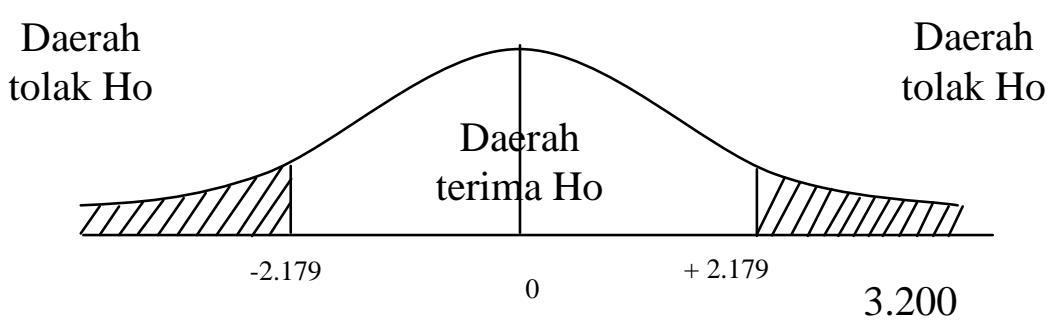

Variabel LAR Untuk mengetahui sejauh mana kebenaran koefisien Regresi untuk variabel LAR digunakan uji t, dengan ketentuan sebagai berikut:

Ho: $\beta 2=0$ : artinya tidak ada pengaruh dari variabel LAR terhadap variabel NPL

Hi : $\beta 2 \neq 0$ : artinya ada pengaruh dari variabel LAR terhadap variabel NPL.
Dengan menggunakan test dua arah, derajat bebas dan taraf nyata $5 \%$, diperoleh nilai $t_{\text {tabel }}$ sebesar 2.179 Sedangkan dengan pengujian statistik diperoleh $t_{\text {hitung }}$ sebesar 0.261 , karena nilai $t_{\text {hitung }}<t_{\text {tabel }}$, maka Ho diterima dan Hi ditolak. Dengan demikian dapat diambil kesimpulan bahwa variabel LAR adalah tidak signifikan pada taraf nyata $\alpha=5 \%$ dengan tingkat kepercayaan $95 \%$.

Gambar 4.

Daerah Penerimaan dan Penolakan $\mathrm{H}_{0}$ dengan menggunakan uji $t$ terhadap variabel LAR

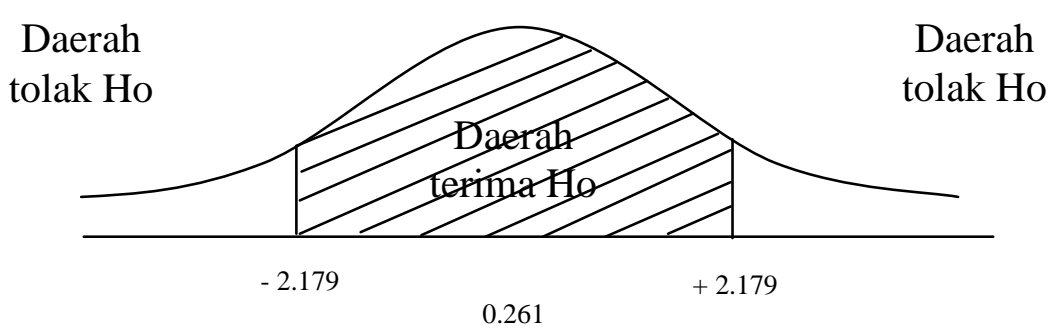




\section{PEMBAHASAN}

Pembahasan dibawah ini akan menjelaskan hubungan antara tujuan penelitian dengan hasil penelitan. Di depan telah dijelaskan bahwa tujuan penelitian adalah untuk mengetahui besarnya pengaruh Pembiayaan yang Diberikan, LAR dan BI rate terhadap NPL untuk kurun waktu tahun 2006 2010.

Dengan berdasar pada hasil perhitungan regresi diperoleh nilai koefisien regresi yang positif antara pembiayaan dengan NPL untuk kurun waktu 2006 - 2010.

Uji $\mathrm{t}$ menunjukkan bahwa $\mathrm{t}$ hitung > $\mathrm{t}$ tabel, hal ini menyatakan bahwa pembiayanan mempunyai pengaruh yang berarti. Sedangkan angka koefisien regresi dalam perhitungan menunjukkan pengaruh variabel pembiayanan terhadap NPL Hal ini menunjukkan bahwa dengan tiap terjadinya peningkatan nilai pembiayaan sebesar $1 \%$ akan meningkatkan NPL.

Pembiayaan merupakan penyediaan uang atau tagihan yang dipersamakan dengan itu berdasarkan persetujuan atau kesepakatan antara bank dengan pihak lain yang mewajibkan pihak yang dibiayai untuk mengembalikan uang atau tagihan tersebut setelah jangka waktu tertentu dengan imbalan atau bagi hasil. Pembiayaan yang diberikan merupakan putusan jumlah kredit yang diberikan bank sesuai dengan batasan jumlah kredit serta segmen bisnis masingmasing.

Besarnya jumlah kredit yang disalurkan akan menentukan keuntungan yang diperoleh. Akan tetapi tidak berarti bahwa jumah kredit yang disalurkan besar akan memberikan keuntungan yang besar pula. Dan hal ini akan berdampak pada tingkat Non Performing Loan perbankan. Untuk itulah perlu adanya kebijakan pemberian kredit yang tepat dan efektif yang diterapkan perbankan agar tingkat kredit bermasalah dapat berkurang.

Kegiatan penyaluran kredit mengandung resiko yang dapat mempengaruhi kesehatan usaha bank. Likuiditas keuangan, solvabilitas dan profitabilitas bank sangat dipengaruhi oleh keberhasilan mereka (bank) mengelola kredit yang disalurkan. pemberian kredit ini memiliki faktor resiko yang cukup tinggi dan berpengaruh cukup besar pula terhadap tingkat kesehatan bank serta tidak menutup kemungkinan terjadinya kredit 
yang bermasalah atau kredit macet yang diberikan.

Dengan berdasar pada hasil perhitungan regresi diperoleh nilai koefisien regresi yang negatif antara LAR dengan NPL untuk kurun waktu 2006 - 2010.

Uji $\mathrm{t}$ menunjukkan bahwa $\mathrm{t}$ hitung $<\mathrm{t}$ tabel, hal ini menyatakan bahwa LAR tidak mempunyai pengaruh yang berarti. Sedangkan angka koefisien regresi dalam perhitungan menunjukkan pengaruh variabel nilai LAR terhadap NPL Hal ini menunjukkan bahwa dengan tiap terjadinya peningkatan LAR sebesar 1 $\%$ akan menurunkan NPL 0.100.

\section{Likuiditas}

merupakan

kemampuan perusahaan guna memenuhi kewajiban-kewajiban jangka pendek. Rasio likuiditas yang digunakan adalah current ratio yaitu perbandingan antara jumlah saldo harta lancar perusahaan dan hutang lancar. Ketersediaan dana dan sumber dana bank pada saat ini dan di masa yang akan datang, merupakan pemahaman konsep likuiditas dalam indikator ini

Menurut Bank Indonesia, penilaian aspek likuiditas mencerminkan kemampuan bank untuk mengelola tingkat likuiditas yang memadai guna memenuhi kewajibannya secara tepat waktu dan untuk memenuhi kebutuhan yang lain. Disamping itu bank juga harus dapat menjamin kegiatan dikelola secara efisien dalam arti bahwa bank dapat menekan biaya pengelolaan likuiditas yang tinggi serta setiap saat bank dapat melikuidasi assetnya secara cepat dengan kerugian yang minimal (SE. Intern BI, 2004).

$$
\text { LAR menunjukkan }
$$

perbandingan antara volume kredit dibandingkan volume assets yang dimiliki oleh bank. Hal ini berarti menunjukkan tingkat likuiditas semakin kecil dan sebaliknya karena assets yang dimiliki telah habis digunakan untuk membiayai financing portofolio kreditnya. Semakin tinggi rasio ini, semakin rendahnya kemampuan likuiditas bank yang bersangkutan sehingga kemungkinan suatu bank dalam kondisi bermasalah akan semakin besar.

\section{PENUTUP}

Berdasar hasil penelitian dan analisa yang telah dibahas pada bab sebelumnya, maka dapat ditarik suatu kesimpulan dan saran sesuai dengan masalah dan tujuan penelitian sebagai berikut:

Dengan berdasar pada hasil perhitungan regresi diperoleh nilai 
koefisien regresi yang positif antara pembiayaan dengan NPL untuk kurun waktu 2006 - 2010.

Gambaran tentang pembiayaan yang disalurkan oleh perbankan syariah dan kualitas pembiayaanya yang dicapai selama 2006-2010 adalah terjadi peningkatan dari tahun ke tahun karena semakin banyaknya nasabah bank yang membutuhkan fasilitas pembiayaan untuk keperluanya, tetapi ini tidak dibarengi dengan Non Performing Loan yang semakin menurun karena masih saja mendekati 5\%. Ini berarti masih saja terjadi kredit bermasalah pada sistem perbankan syariah di Indonesia.

Berdasarkan hasil analisis diketahui bahwa Pembiayaan yang diberikan, LAR secara serempak berpengaruh signifikan terhadap Non Performing Financing yang ditunjukkan dengan nilai $\mathrm{F}$ tabel (3.89) lebih kecil dari F hitung (5.266)

Dari hasil analisis data dapat ditarik kesimpulan bahwa Pembiayaan yang diberikan berpengaruh terhadap Non Performing Financing adalah dengan koefisien 0.677 sedangkan LAR tidak berpengaruh signifikan terhadap NPL

Perbankan seharusnya lebih berhati-hati dalam pemberian kredit atau pembiayaan terhadap para nasabahnya, adanya pengecekan dan persyaratan yang lebih detail jika nasabah ingin mengajukan kredit atau pembiayaan, perlu diadakan restrukturisasi pembiayaan kembali agar hutang tidak terlalu banyak pada perbankan, sehingga dapat mempengaruhi kualitas pembiayaan pada perbankan syariah.

\section{DAFTAR PUSTAKA}

Adnan Akhyar. 2005. Analisis Hubungan Simpanan, Modal Sendiri, NPL, Prosentase Bagi Hasil Dan Markup Keuntungan Terhadap Pembiayaan Pada Perbankan Syariah. Sinergi Edisi khusus on Finance. Yogyakarta: Universitas Islam Indonesia

Adiningsih, Sri. 2000. Comparing Banking Crisis: The Indonesia and Norway Cases. Gajah Mada University. Oktober

Arifin, Johar dan Fakhruddin, Muhammad. 2000. Kamus Istilah Pasar Modal, Akuntansi, Keuangan dan Perbankan. Elex Media Komputindo. Jakarta

Asrof, M. 1994. Manajemen Penyelamatan Kredit atas Kredit Bermasalah. Institut Bankir Indonesia, No.47, pp. 65-76

Bank Indonesia dalam Inflation Targetting Framework

Firdaus, Rachmat dan Ariyanti, Maya. 2003. Manajemen Perkreditan bank Umum-Teori, Masalah, 
Kebijakan dan Aplikasinya lengkap dengan Analisis Kredit. Alfabeta. Bandung

Ghozali, Imam. 2001. Aplikasi Analisis Multivariate dengan Program SPSS. Badan Penerbit Undip. Semarang

Gujarati, Damodar N. 2006 (United States Military Academy, West Point). Essentials of Econometrics. Third Edition. McGraw-Hill International Edition.

Hasibuan, Nurdin. 1994. Perkembangan Kredit Macet dan Permasalahanya.

Pengembangan Perbankan Institut Bankir Indonesia, No.47, pp. 2341

Joyosumarto, Soebardjo. 1994. Upaya upaya Bank Indonesia dalam Menyelesaikan Kredit Bermasalah. Pengembangan Perbankan Institut Bankir Indonesia, No.47, pp 9-22

Karim, Adiwarman. 2004. Bank Islam Analisa Fiqih dan Keuangan. PT Raja grafindo Persada. Jakarta

Mahmoeddin, As. 2002. Melacak Kredit Bermasalah. Pustaka Sinar Harapan. Jakarta

Muhammad. 2000. Sistem dan Prosedur Operasional Bank Islam. UII Press. Jogjakarta

Muhammad. 2001. Pengantar Akuntansi Syariah. Salemba empat. Jakarta
Muhammad. 2002. Manajemen Bank Syariah. UPP AMK YKPN. Yogyakarta

Nasution dan Williasih. 2007. Profit Sharing dan Moral Hazard dalam Penyaluran Dana Pihak Ketiga Bank Umum Syariah di Indonesia. Jurnal Ekonomi dan Pembangunan Indonesia Vol. VII No. 02, hal 105-129

Peraturan Bank Indonesia Nomor 13/9/PBI/2011 tanggal 18 februari 2011 tentang Perubahan atas PBI Nomor 10/18/PBI/2008 tentang Restrukturisasi Pembiayaan bagi Bank Syariah dan Unit Usaha Syariah (UUS)

Peraturan Bank Indonesaia Nomor tanggal 30 Mei 2011 mengenai Restrukturisasi pembiayaan perbankan syariah

PSAK Nomor 31 (Revisi 2000)

Rose, Peter S. dan James W.Kolari. 1995. Financial Institution: Understanding and managingfinancial services. Richard D.Irwin, Inc., USA

Setiajatnika, Eka. 2012. Jurnal Keuangan

Siamat, Dahlan. 2004. Manajemen Lembaga Keuangan. Intermedia. Jakarta

Siamat, Dahlan. 2005. Manajemen Lembaga Keuangan: Kebijakan Moneter dan Perbankan. FE UI. Jakarta

Soehardjono. 2003. Manajemen Perkreditan Usaha Kecil dan 
Menengah. UPP AMP YKPN. Jogjakarta

Surat Edaran Intern Bank Indonesia. 2004

\section{Surat Keputusan Direksi Bank Indonesia No. 30/267/KEP/DIR/1998 tentang Kualitas Aktiva Produktif Pasal 4}

Syafi'i Antonio, Muhammad.2001. Bank Syariah dari teori kepraktek, Gema Insani Press, Jakarta

Tangkilisin, Hessel Nogi S. 2003. Manajemen Keuangan Bagi Analisi Kredit Perbankan: Mengelola Kredit Berbasis Good Corporate Governance. Balairung dan Co. Jogjakarta

Undang - Undang Nomor 10 Tahun 1998 tentang Perbankan

Undang - Undang Nomor 23 Tahun 1999 tentang Bank Indonesia Mengatur Perkembangan Pengembangan Perbankan Syariah di Indonesia

Undang - undang Nomor 23 Tahun 1999 Pasal II dan VIII Bab 4 Poin 1 tentang Bank Indonesia
Undang - Undang Nomor 10 Pasal 1 butir 13 Tahun 1998 tentang Prinsip Syariah

Undang - Undang Nomor 10 Tahun 1998 Pasal 1 butir 2 tentang Perubahan Atas Undang-undang Nomor 7 Tahun 1992 Tentang Perbankan

Undang - Undang Nomor 10 Tahun 1998 Pasal 1 butir 3 tentang Perubahan Atas Undang-undang Nomor 7 Tahun 1992 Tentang Perbankan

Undang-Undang Nomor 21 Tahun 2008 Pasal 1 Poin 25 tentang Perbankan Syariah

Zainul Arifin. 2000. Memahami Bank Syariah: Lingkup, Peluang, Tantangan dan Prospek. Jakarta: Alvabet

www.bi.go.id . Surat Edaran Bank Indonesia. Diakses tanggal 3 maret 2012

www.syariahmandiri.co.id .Annual Report. Diakses tanggal maret 2012

www.muamalatbank.com .Annual Report BMI. Diakses tanggal 6 maret 2012

www.bsmi.co.id . Annual Report. Diakses tanggal 6 maret 2012 